\title{
The drivers of water abstraction and river water diversion in tropical rivers: a case of south west upper tana basin, Kenya
}

\begin{abstract}
The study to determine the drivers of water abstraction and river water diversion in tropical rivers was undertaken in four rivers that constitute the South West Upper Tana Basin in Kenya. Rainfall and river discharge data for the period between years 1998 and 2018, water abstraction data and field survey data collected through questionnaires was used in this study. The water abstraction data was collected for a period of one year, from January 2018 and December 2018. The analysis of the drivers was guided by the DPSIR framework. Regression and correlation analysis was used to test the nature and strength of relationship of variables respectively. The results of the study indicate that the main drivers of water abstraction and river water diversion are climate change, government policies and strategies, agricultural development and population pressure. $60 \%$ of the people in this basin rely on agriculture hence irrigation agriculture has intensified water abstraction in the basin. There is a significant positive relationship between water abstraction and crop production with a correlation coefficient of 0.78 and coefficient of determination of 0.73 . The study also established that water abstraction increased during dry season and when the rainfall received in the area decreases. The relationship between rainfall and streamflow show that increase in rainfall leads to subsequent increase in streamflow with a correlation coefficient of 0.70 and coefficient of determination of 0.61 . Government policies of intensifying irrigation agriculture in order to improve food security and inter basin water transfers to improve water supply in urban and rural areas have increased water abstraction in the basin. The study recommends frequent monitoring of the rivers by authorities and licensing of all water abstractors to improve sustainability in the abstraction of water.
\end{abstract}

Keywords: water abstraction, river water diversion, streamflow, DPSIR, SWUT Basin, agriculture
Volume 3 Issue 2 - 2019

\author{
Philip K Mwendwa, Johnson U Kitheka, \\ Mwangi Moses, Otieno Hesbon \\ Department of Hydrology and Aquatic Sciences, School of \\ Water, Environment and Natural Resources, South Eastern \\ Kenya University, Kenya
}

Correspondence: Philip K Mwendwa, Department of Hydrology and Aquatic Sciences, School of Water, Environment and Natural Resources, South Eastern Kenya University, P.O Box 170-90200 Kitui, Kenya, Email philkimms@gmail.com

Received: April 4, 2019 | Published: April 16, 2019

\section{Introduction}

Rivers are important freshwater resources that are important in supporting and sustaining socio-economic systems in the world. However, the distribution of these freshwater resources is erratic and unreliable. Thus, man has always tried to exploit these resources by diverting river water to satisfy different needs. In tropical river basins, river water diversions has been done as a flood control measure and also to improve urban and rural water supplies, avail water for irrigation and generate hydropower. ${ }^{1}$ The escalating demand for hydropower, irrigation and domestic water is likely to increase water abstractions in rivers. ${ }^{2-4}$ River basins in the world are facing multiple stressors including pollution, infrastructure developments like dams, eutrophication and land use changes. ${ }^{5}$ Limited studies have been undertaken to determine drivers of water abstraction and river water diversions in Kenya. In addition, the studies undertaken have mainly concentrated on water supplies and urban water demands. There is limited data on the root causes of water abstraction and river water diversion in tropical river basins. This study will fill this gap by establishing the main drivers of water abstraction and river water diversion in South West Upper Tana Basin. In South West Upper Tana, there are many low magnitude river diversions which are not documented. These diversions are necessitated by water needs such as irrigation agriculture, recreation, domestic use, and rural and urban supplies. However, it is not been established which of these water needs is the most dominant in the basin. Poor licensing and monitoring of water abstractions and river diversions in the basin has led to increased water abstractions in the basin and unintended consequences that has greatly affected the flow of rivers in the basin. The declining streamflow in the basin is a major concern since it affects the livelihoods in the region, degrades the aquatic ecosystem and affects the rural and urban water supplies in the area. ${ }^{6,7}$ Thus, it is important to understand the main drivers of these abstractions in order to formulate policies and strategies to improve sustainability of the water resources. This study seeks to determine how these drivers interact categorically, synergistically and additively by applying the DPSIR framework.

Rivers in South West Upper Tana Basin are important sources of water for Nairobi City. Through Ndakaini dam, rivers in this basin supply $84 \%$ of water to Nairobi City (Athi Water Services Board, 2014). Thus, there is a need to understand the drivers of water abstraction in this basin since they may affect the streamflow in the rivers in this basin which could lead to inadequate water supply in the city. In addition, for Kenya to attain Vision 2030 and attain Sustainable Development Goal number 6 of clean water and sanitation, sustainable 
management of water resources is important. The main objective of this study was to determine the drivers of water abstraction and river water diversion in South West Upper Tana Basin in Kenya.

\section{Description of the study area}

\section{Location}

The South West Upper Tana Basin is located in Muranga County and partly in Kiambu County, Kenya. The basin lies between latitudes $0^{\circ} 34^{\prime}$ South and $1^{\circ} 7^{\prime}$ 'South and Longitudes $36^{\circ}$ East and $37^{\circ} 27^{\prime}$ East. The basin covers a total surface area of $2,558.8 \mathrm{Km}^{2}$ with an elevation of between 1,340 $\mathrm{m}$ above sea level to the east and 2,190 $\mathrm{m}$ above sea level to the west. ${ }^{8}$ The main rivers in the study area (Kiama, Kimakia, Chania and Thika) originate from the Aberdare mountain ranges in the west and flow eastwards, dissecting the steep slopes in the area. Kimakia and Chania River intersect at Ng'ethu while Kiama and Thika River intersect after Gatanga. ${ }^{9}$ The rivers then join at Ndururumo to form Thika River which flow to River Tana (Figure 1).

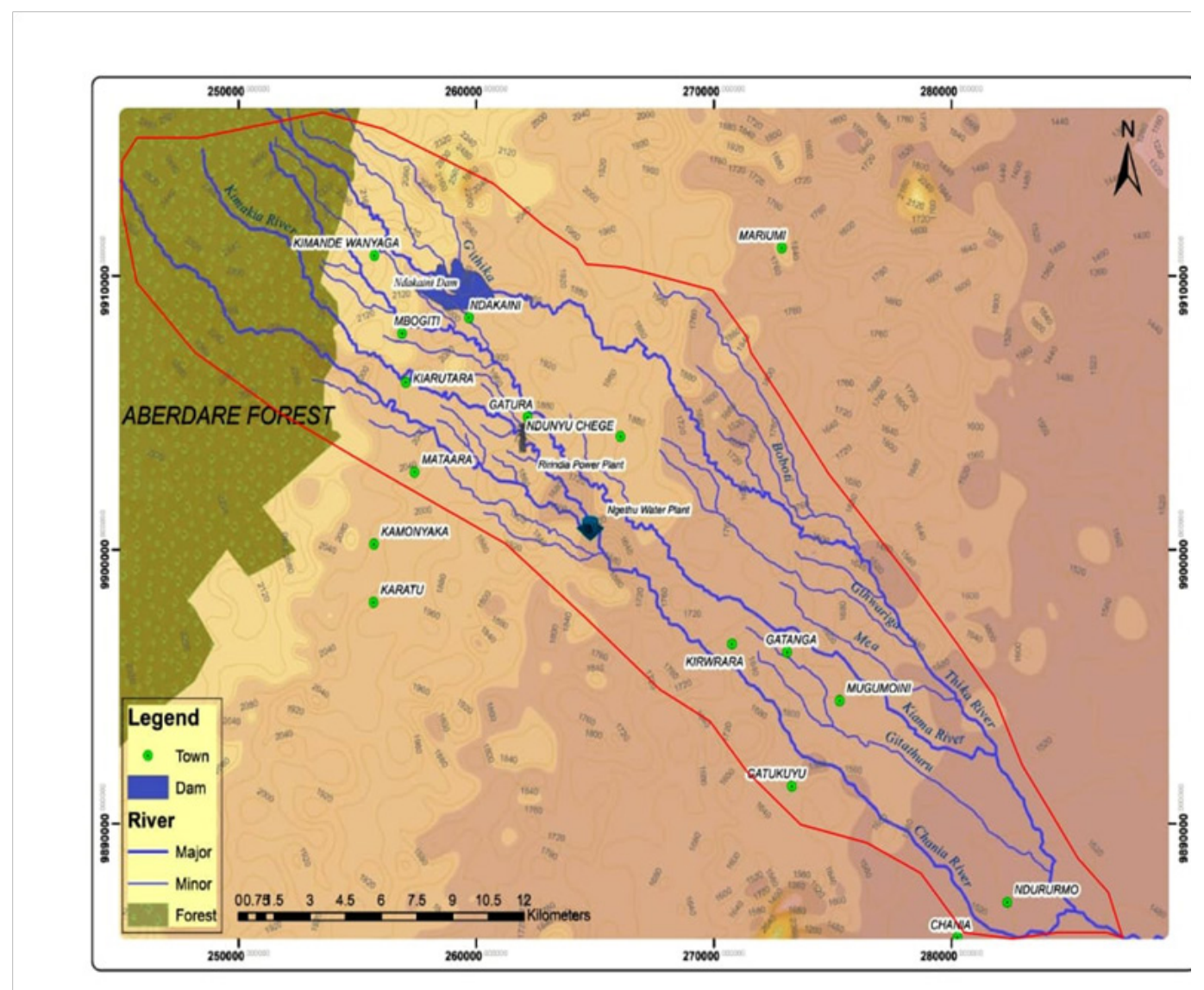

Figure I Location of the main rivers in South West Upper Tana Basin.

\section{Climate}

Rainfall in the study area is influenced by the monsoon winds that occasionally blow from the Indian Ocean and the Aberdare Mountain ranges. These winds blow through the area twice a year leading to a bimodal rainfall distribution with long rainy season occurring between March and May and short rain season occurring between October and December. ${ }^{10,11}$ There are dry seasons in between the two rainy seasons that are caused by the persistent North Easterly Moonsoons. The highest annual rainfall in the study area is $1800 \mathrm{~mm} / \mathrm{yr}$. received in the higher altitudes of Aberdare Mountain ranges while mid attitudes receive rainfall amounting between 1000 to $1800 \mathrm{~mm} / \mathrm{yr}$. The low altitude areas receive less than $700 \mathrm{~mm} / \mathrm{yr} .{ }^{12}$ Temperatures in the area are regulated by altitude with the lower altitude areas experiencing a maximum of $26^{\circ} \mathrm{C}$. The higher altitude areas in the Aberdare Mountain ranges experience a maximum of $18^{\circ} \mathrm{C}$ and lowest temperatures of $6^{0} \mathrm{C}$. The hottest month in the study area is February while the coldest month is July. The mean annual potential evaporation in the study area is between $2300 \mathrm{~mm}$ in the lower altitudes and $1200 \mathrm{~mm}$ in the Aberdare mountain ranges. ${ }^{13}$

\section{Soils}

The main soils in this basin are nitosols, cambisols and andosols. In the high altitude areas (1800 to $2190 \mathrm{~m}$ above sea level) there are dark coloured soils that are rich in organic matter. In the lower slopes $(<1800 \mathrm{~m}$ above sea level), soils are highly influenced by the amount of rainfall received. For instance, areas that receive high rainfall have red soils with traces of clay. ${ }^{14}$ 


\section{Geology}

The geology of this area mainly consists of volcanic rocks of Pleistocene age and basement system rock of Achaean type. ${ }^{14}$ Volcanic rocks are dominant on the western part of the study area extending into the Aberdare mountain ranges while on the eastern part of the study area, rocks of the basement system are found. ${ }^{9}$ On the southern and the eastern margin of the study area, there are outcrops of preCambrian basement rocks. ${ }^{13}$

\section{socio-economic activities}

Most people in SWUT basin are farmers with crop farming being the most dominant activity. $98 \%$ of the people in this basin grow cash crops such as tea and coffee and subsistence crops. ${ }^{15}$ Food crops such as potatoes, bananas, pineapples and cereals as well as horticultural crops are also grown in this basin. Dairy and beef farming are also practiced while pig farming is widespread in the study area. ${ }^{16}$ Other economic activities in the area include forestry and wildlife in the upper parts of Aberdare, Kieni, Kimakia and Gatare forests. ${ }^{16}$ The high population in the area has led to subdivision of land into small plots averaging 2 Acres or less. ${ }^{15}$

\section{Population}

The population in this basin is estimated to be 163,597 people. ${ }^{17}$ This translates to 276 people $/ \mathrm{km}^{2}$. The female population $(82,610)$ is slightly higher the male population $(80,987)$. The high female population in the basin can be attributed to the emigration of male population to towns in the area in search of employment. ${ }^{8}$ The upper parts of the study area that lie in the Aberdare forest have the least population density of 0.06 people $/ \mathrm{km}^{2}$. This is mainly because this area is a protected zone since it is a major water catchment area in Kenya.

\section{Methodology}

\section{Rainfall and river discharge data}

Rainfall data for this study was obtained from the Kenya Meteorological Department (KMD) for Gatare forest station, Thika meteorological station and Thika dam. Rainfall data for these stations was available for the period between 1998 and 2018. This data was important in determining whether rainfall changes are a major driver of water abstraction in SWUT basin. River discharge data was obtained from Water Resources Authority (WRA) for RGS 4CB5, RGS 4CA15, RGS 4CA19. Data for these stations was available for a period of 20 years, between 1998 and 2018.

\section{Water abstraction Data}

Water abstraction data was obtained from the field using questionnaires where the entire basin was sub divided into four (4) sub basins. Twenty five (25) questionnaires were administered in each sub basin, fifteen (15) in the upstream and ten (10) in the downstream. These questionnaires were randomly administered in households for a period of twelve (12) months then daily, monthly and annual abstraction rates calculated. The mean monthly water abstraction rates were calculated as follows;

$$
\bar{Q}_{a b s(m)}=\sum_{i=1}^{i} Q_{a b s(d)}
$$

Where $\bar{Q}_{a b s(m)}$ the total monthly water abstraction is rate (in litres) and $Q_{a b s(d)}$ is the daily water abstraction rate.

Annual water abstraction rates were calculated as;

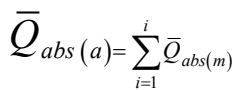

Water abstraction data was also obtained from the WRA archives. This data, however, only included water abstraction from licensed abstractors.

\section{Target population size and sample size}

Population for this study involved households that abstract water from the four rivers in the SWUT basin. Twenty five (25) questionnaires were administered in each sub basin, fifteen (15) upstream and ten (10) downstream. Institutions, organisations and large irrigated farms in the study area also formed part of the study population. The sample size was determined using Cochran formula as follows;

Where;

$$
n=\frac{z^{2} p q}{e^{2}}
$$

$\mathrm{n}$ is the sample size, $\mathrm{P}$ is the estimated proportion of an attribute present in the population $(0.5), q$ is $1-p, z^{2}$ is abscissa of the normal curve that cuts off an area $\alpha$ at the tails (value of $z$ obtained from the statistical table). This yielded a sample size of 96.04 rounded off to 100 households.

\section{Determination of the influence of agricultural practices on water abstraction}

To determine how agricultural practices were influencing water abstraction, questionnaire surveys, field based observations and review of secondary data was done. Data on farm size, crops grown, income from crops and best time to sell crops was collected. Excel statistical package was used to establish the relationships between water abstraction and agricultural practices. Analysis of Variance (ANOVA) was done to establish if there was any statistical difference between the means of samples obtained from different variables in the four rivers.

\section{Data analysis}

The statistical methods used to analyse data in this study were parametric tests, descriptive statistics, correlation analysis, regression analysis and Analysis of Variance (ANOVA). The descriptive statistics used include mean, standard deviation, percentages and cross tabulation. Parametric tests were used to test the influence of several drivers to ascertain the drivers with the influence on water abstraction in SWUT basin. T-test was used because of its ability to compare the means of two independent variables. ${ }^{18}$ Simple and multiple regression analysis were used to establish the nature of relationship between variables. For instance the relationship between rainfall and water abstraction, agricultural practices and water abstraction and population changes were established. Simple linear regression analysis was calculated as follows;

$$
Y=a+b X+e
$$


Where $\mathrm{Y}$ is the independent variable, $\mathrm{a}$ and $\mathrm{b}$ are the numerical constants, $\mathrm{X}$ is dependent variable which was water abstraction and $\mathrm{e}$ is the error term.

Multiple linear regression analysis was calculated as follows;

$$
y=\beta o+\beta 1 X 1+\beta 2 X 2+\cdots+\beta k X k+\varepsilon
$$

Where $\mathrm{Y}$ is the dependent variable (water abstraction), $X 1, X 2, \ldots$, are the independent variables for instance income from crops, farm size, household size, amount of fertilizer used, type of crop grown and technology used. $\beta 1, \beta 2, \ldots$, are Beta coefficients and " $k$ " is the number of independent variables. $\varepsilon$ is the random error taken to be a random variable with variance $(\sigma 2)$ and mean 0 . To explain the strength of relationships, correlation analysis was done. The strength of relationship between water abstraction and agricultural practices, water abstraction and household characteristics, water abstraction and technologies used and water abstraction and population changes were determined.

\section{Results of the study}

\section{Effect of rainfall variability on water abstraction}

The patterns of water abstraction rates in the four sub basins in SWUT basin were found to be similar. In the four basins, water abstraction is highest in the dry periods between May and September and between January and March. Water levels in the period between May and September decreases from $0.78 \mathrm{~m}$ to $0.24 \mathrm{~m}, 1.01 \mathrm{~m}$ to $0.5 \mathrm{~m}$, $0.83 \mathrm{~m}$ to $0.41 \mathrm{~m}$ and $0.83 \mathrm{~m}$ to $0.4 \mathrm{~m}$ in Thika, Kiama, Chania and Kimakia rivers, respectively. The water level also decrease in the period between November and February from $0.79 \mathrm{~m}$ to $0.38 \mathrm{~m}, 1.5 \mathrm{~m}$ to $0.58 \mathrm{~m}, 0.99 \mathrm{~m}$ to $0.41 \mathrm{~m}$ and $0.89 \mathrm{~m}$ to $0.41 \mathrm{~m}$ in Thika, Kiama, Chania and Kimakia rivers respectively (Figure 2). The periods of low water levels in the rivers coincide with the period of high water abstraction rates. Maximum water abstraction rates of 107,2001/d, 95,5001/d, $63,4001 / \mathrm{d}$ and 66,900 1/d in Thika, Kiama, Chania and Kimakia rivers, respectively is in the months of September and January (Figure 3). These are the driest months in the study area. The low rainfall in these periods drives people to abstracting more water from the rivers which subsequently lowers the water levels in the rivers. The statistical relationship between water abstraction and river water level yielded a correlation coefficient $r$ of 0.51 and coefficient of determination $R^{2}$ of 0.46 at $95 \%$ confidence level.

\section{Influence of household characteristics on water abstraction}

It was established that most of the households in the study area have an average of 5 members. Most of these households abstract less than $10,000 \mathrm{l} / \mathrm{d}$. Households with the highest abstraction rates between $15,000 \mathrm{l} / \mathrm{d}$ and $40,000 \mathrm{l} / \mathrm{d}$ have 2 to 6 members. These results are consistent with Mwadini. ${ }^{19}$ The study established a weak statistical relationship between water abstraction and household size with a correlation coefficient $\mathrm{r}$ of 0.01 and coefficient of determination $\mathrm{R}^{2}$ of 0.005 at $95 \%$ confidence level $(\mathrm{P}=0.05)$. This could be attributed to the fact that most people abstracting water from the rivers in the basin do so for farming. Thus, some small households abstract more water than larger households by procuring water abstraction technologies such as water pumps. This, however, contradicts the findings of Aseyehegn et al., ${ }^{20}$ Zhang ${ }^{21}$ who noted a positive relationship between household size and water abstraction. Majority of the people abstracting water in this basin are between the ages of 25-55 years old. This could be attributed to the fact that majority of the people in this age group have relatively young families to take care of hence they abstract water to improve farm production and income. The study established a weak relationship between age and water abstraction with correlation coefficient $r$ of 0.052 and coefficient of determination $\mathrm{R}^{2}$ of 0.049 at $95 \%$ confidence level. ${ }^{22-24}$ This study established that most of the people living in this basin have low levels of education since $69 \%$ of the respondents have only acquired secondary school education (54\%) and Primary school (15\%). The low education levels could be one of the reasons why most people abstract water from the rivers in this basin since they cannot secure any form of formal employment. The low education level also means that the people lack adequate knowledge on the sustainable water abstraction methods. This is consistent with Alufah, ${ }^{25}$ Chebil et al., ${ }^{26}$ and Getacher et al., ${ }^{27} 50 \%$ of the people in the study area are farmers who rely on irrigation farming to boost their crop production in the dry season (Table 1). Attempt was made to determine the influence of income levels on water abstraction. It was established that $74 \%$ of the people in the study area earn between Kshs 5,000 and Kshs 20,000 per month. Only 4\% of the people living in the study area earn more than Kshs 30,000per month. The low income levels drives many people to abstract water for irrigation agriculture to enable them obtain enough income to cater for the needs of their families.

\section{Influence of water abstraction technologies on water abstraction}

The main water abstraction technologies in SWUT basin are buckets and 201 jerricans, pumps, siphons, diversion canals and pipes. $40 \%$ of the people abstracting water from the basin use buckets, $26 \%$ use diversion canals, $25 \%$ use pumps while $8 \%$ use pipes and siphons. Buckets are common because they are cheap to acquire and easy to use. Water pumps are popular among farmers with large farms and those earning higher income that can enable them to buy and maintain the water pumps. ${ }^{28,29}$ The study established that there is a weak correlation coefficient $\mathrm{r}$ of 0.071 and coefficient of determination $\mathrm{R}^{2}$ of 0.04 . These were statistically significant at $95 \%$ confidence level $(\mathrm{P}=0.05)$.

\section{Influence of agricultural practices on water abstraction}

This study established that most of the farms in the study area are 0.5 acres and 3 acres. ${ }^{8,30,31}$ The main crops grown under irrigation in the study area are mainly horticultural. The unreliability of rainfall in the study area has led to increase in irrigation farming in the study area. An attempt was made to establish the reason why many farmers resorted to irrigation farming. It was noted that farmers practicing irrigation farming produce higher crop yields that enable them to obtain more income from crop sales. The relationship between water abstraction and crop sales yielded a correlation coefficient $\mathrm{r}$ of 0.78 and coefficient of determination $\mathrm{R}^{2}$ of 0.78 (Figure 4). In addition, farmers with higher acreage of land under irrigation are able to obtain more income from the sale of crops. The relationship between crop sales and farm size yielded a correlation coefficient $r$ of 0.84 and coefficient of determination $\mathrm{R}^{2}$ of 0.70 . The study established that trading patterns influence water abstraction for irrigation in the study area. It was established that $39 \%$ of farmers in the study area sell their produce to the local markets while $36 \%$ of the produce is sold to other counties in Kenya. 


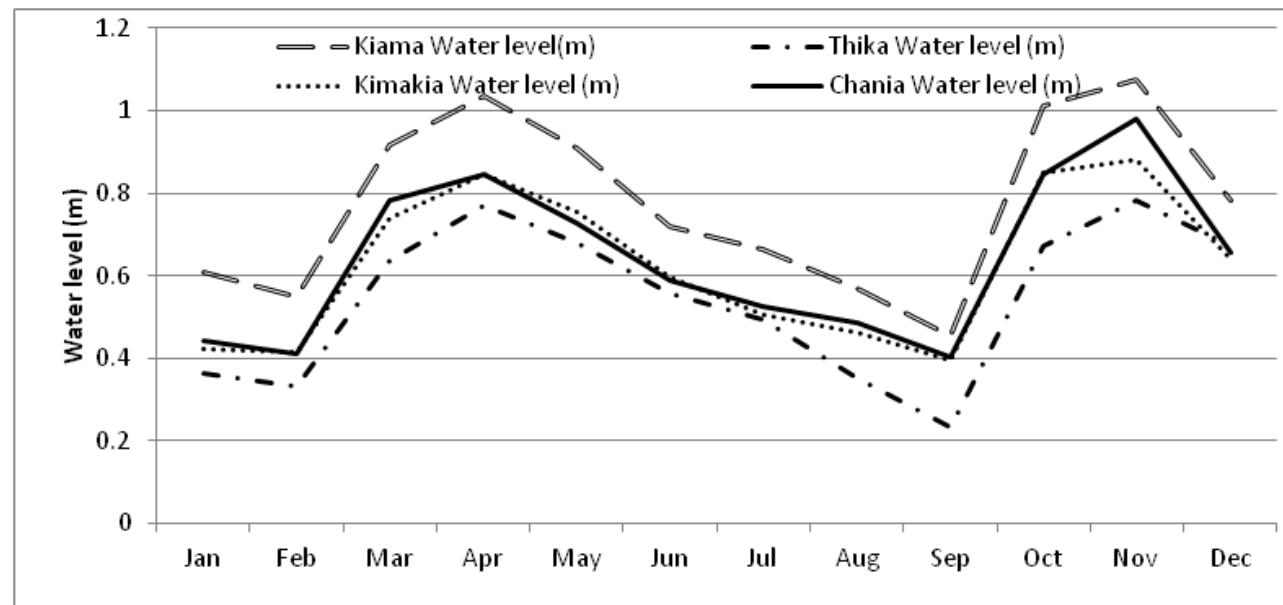

Figure 2 Water levels in rivers in SWUT basin in 2018.

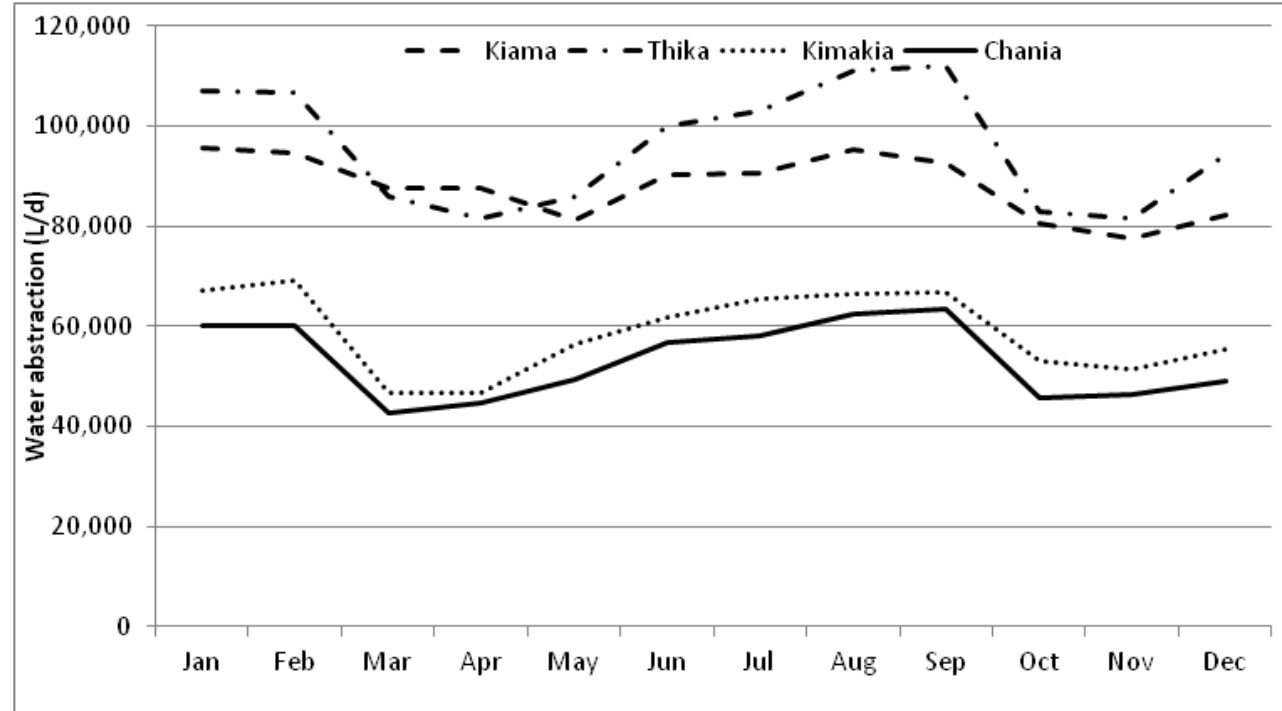

Figure 3 Water abstraction rates in rivers in SWUT basin in 2018.

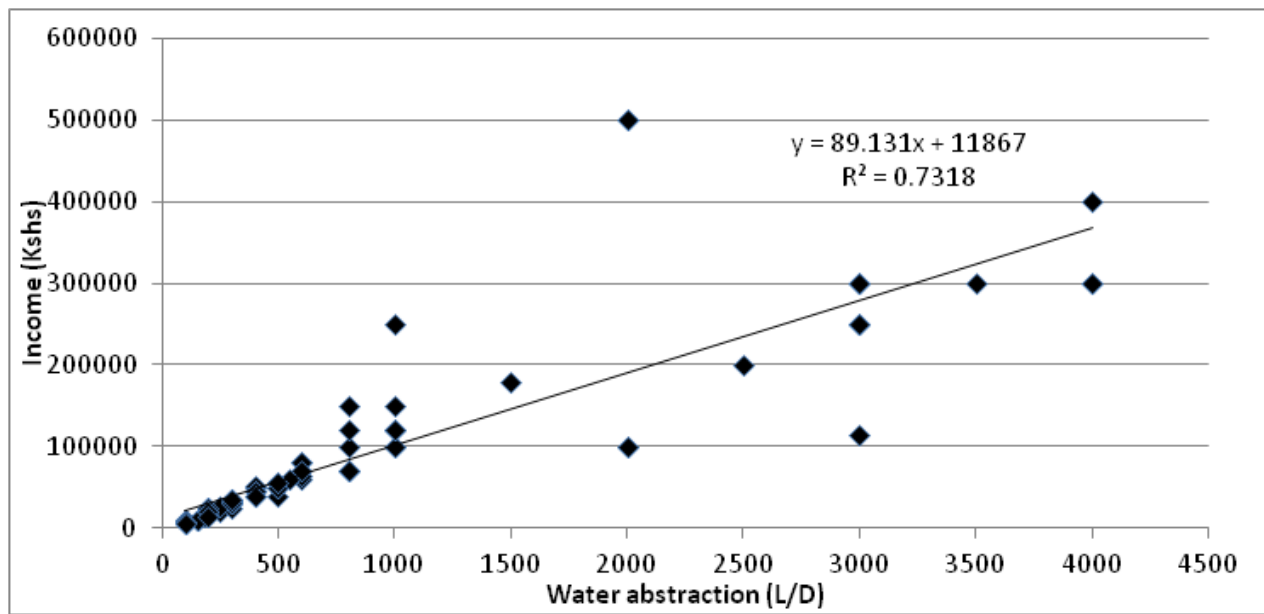

Figure 4 Relationship between water abstraction and crop sales in SWUT basin. 
Table I Occupation of respondents in south west upper tana sub basin

\begin{tabular}{lllllll}
\hline Sub-basin & \multicolumn{6}{l}{ Occupation/percentage (\%) } \\
\cline { 2 - 7 } & Farming & Teaching & Business & Informal sector & Civil service & County government \\
\hline Chania & 57 & II & 14 & 4 & 7 & 7 \\
Thika & 63 & 3 & 8 & 5 & 10 & 11 \\
Kimakia & 61 & & 8 & 11 & 6 & 14 \\
Kiama & 49 & 8 & 20 & 8 & 10 & 5
\end{tabular}

\section{Influence of population growth on water abstraction}

Population in the SWUT basin has tremendously grown over the last 50 years. The population grew from 64,619 people in 1969 to 163,597 in 2017. This increase in population has led to increased demand for water resources. Ngigi et al., ${ }^{32}$ noted that increasing population in the basin has led strain on the available water resources since most farmers have ventured into irrigation agriculture. ${ }^{33}$ Population change from rural to urban has also placed the urban areas as water scarce. To cater for the growing demand for water in the urban areas, the government has come up with various water abstraction and river diversion projects such as the Ndakaini dam and the ongoing Northern Collector Tunnel. The projected increase in population will increase the water abstraction rates in the study area. This is consistent with Howard et al., ${ }^{34}$ and Mokaya ${ }^{35}$ (Figure 5).

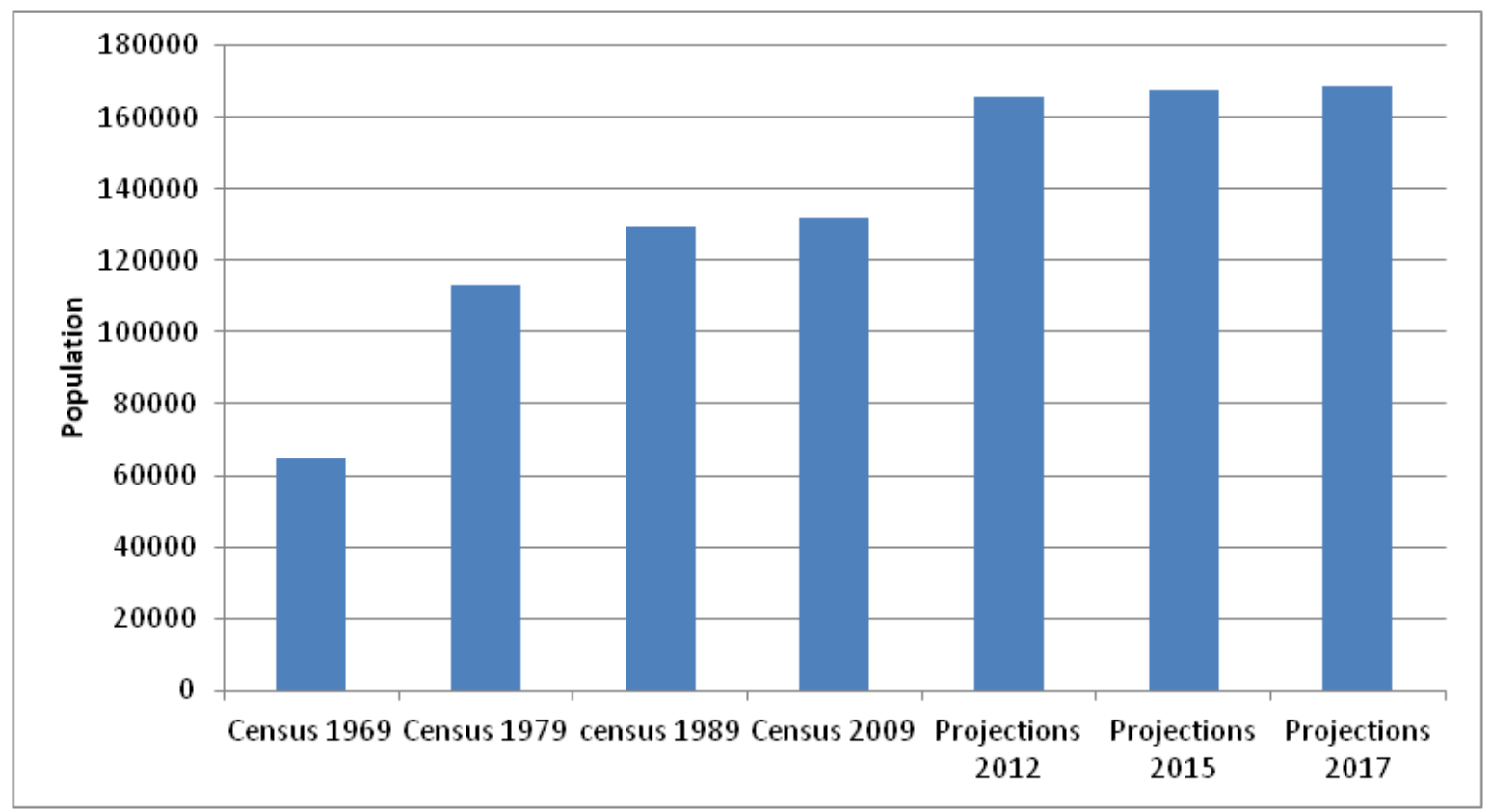

Figure 5 Population Changes in SWUT Basin (Source: Murang'a County Development Planning Office).

\section{Discussion}

\section{Effects of rainfall on water abstraction}

The study established that there is a significant relationship between water abstraction and rainfall variability. It was evident that decrease in rainfall leads to increase in water abstraction. Years that have experienced high rainfall recorded increased streamflow since water abstraction rate was low. The relationship between rainfall and streamflow yielded a correlation coefficient $r$ of 0.70 and coefficient of determination $\mathrm{R}^{2}$ of $0.61 .{ }^{35-38}$ The results of this study showed that during the dry season, rivers in the SWUT basin have the lowest water levels. Water abstraction increases during this period due to the high demand for irrigation water leading to mean water level of $<0.5$ $\mathrm{m}$. These results agree with Liniger et al. ${ }^{39}$ and TNC, ${ }^{15}$ who noted that during the dry period, water abstractions reduce the base flow in rivers. The study established a strong relationship between water abstraction and streamflow with a correlation coefficient $r$ of 0.51 and coefficient of determination $\mathrm{R}^{2}$ of 0.46 . These were statistically significant at $95 \%$ confidence level $(\mathrm{P}=0.05)$. The impacts of water abstraction on streamflow were more evident during the dry season, since farmers need more water to irrigate their farms. However, during the rainy season, the impacts were less evident since farmers reduce water abstraction during rainy season.

\section{Influence of household characteristics on water abstraction}

The mean family size in the study area was established to be 4 members with $81 \%$ of the households having between 3 and 5 years. It was established that the relationship between water abstraction and household size is weak with a correlation coefficient $\mathrm{r}$ of 0.01 
and coefficient of determination $\mathrm{R}^{2}$ of 0.005 . Thus, some smaller households abstract more water than larger households since other factors such as the technology used income of the farmer. ${ }^{19}$ The study established that most of the people abstracting water from the basin were aged between 30 and 50 years. This can be attributed to the fact that at this age most of the people have relatively young families that they have to take care of. Thus, they abstract more water for irrigation to produce more from the farms for their families. Water abstraction rate is low among those aged above 50 years since at that age most of the people are retirees and do not have a lot of energy to invest in irrigation farming. ${ }^{22-24}$ The relationship between age and water abstraction yielded a correlation coefficient $r$ of 0.052 and a coefficient of determination $\mathrm{R}^{2}$ of 0.049 . These were statistically significant at $95 \%$ confidence level. ${ }^{40} 56 \%$ of the people abstracting water in the basin are women. This could be attributed to the high number of female headed families in the study area. The high emigration rate by men to the urban centers in search of employment could also be the reason why women are more dominant in water abstraction. ${ }^{14,41}$ Educational level of the people in the study area also affects water abstraction. It was established that majority of the people abstracting water from the four rivers in the basin have only acquired secondary school education. This limits their chances of securing a formal employment; hence irrigation farming is their only source of livelihood. The study also established that majority of the people who are employed earn between Kshs 5,000 and Kshs 20,000 per month. This low income drives more people to water abstraction for irrigation farming to improve their monthly income. This is consistent with Rutasire et al., ${ }^{42}$ who established that the occupation of the household head determines water abstraction rate and the agricultural activity the family engages in. This also agrees with the findings of Chebil et al., ${ }^{26}$ and Mwangi. ${ }^{43}$

\section{Influence of abstraction technologies on water abstraction}

This study established that water abstraction technologies influence water abstraction rates. Most of the water abstractors use buckets and 201 jerricans to abstract water from the rivers. Buckets are popular since they are cheap to acquire and relatively easy to use. $26 \%$ of the water abstractors use diversion canals. These are, however, not popular because they require constant silt removal especially in the rainy season. Water pumps are popular with $25 \%$ of water abstractors. The pumps are only used by people with large irrigated farms and those earning high income because they are expensive to acquire and maintain. ${ }^{19,29}$

\section{Influence of agricultural practices on water abstraction}

It was established that irrigation agriculture is the main cause of water abstraction in the study area. There is a strong positive relationship between water abstraction and crop sales with a correlation coefficient $\mathrm{r}$ of 0.78 and coefficient of determination $\mathrm{R}^{2}$ of 0.73 . This could be attributed to the fact that more water abstraction allows the farmer to do farming all year round. There is also a significant relationship between crop sales and farm size with a correlation coefficient $r$ of 0.85 and coefficient of determination $\mathrm{R}^{2}$ of 0.75 . Thus, farmers with higher acreage of land under irrigation earn more from the crop sales since they are able to produce more crop yields from their farms. This is consistent with the findings of Speelman (2009) who established a significant relationship between water abstraction, farm size and the crop grown. Similarly, Michailidis et al., ${ }^{44}$ established that irrigation agriculture contributes the highest water abstraction volumes in the developing countries. ${ }^{39,45,46}$ Most of the farm produce is sold during the dry season, an indicator that only farmers who practice irrigation farming produce more yields even in dry season. ${ }^{47-49}$

\section{Conclusion}

The study concluded that the increasing rainfall variability in SWUT basin has led to increase in water abstraction. This is mainly the case during dry seasons since farmers need to abstract more water for irrigation agriculture. Water abstraction increases from the months of May to September (dry season) and the months of December to February. The abstraction rate decreases with the onset of short rains between the months of October and November and long rains between the months of March and May. Agricultural practices such as farm size and the income generated from sale of crops have a significant influence on water abstraction. The study established a strong positive relationship between water abstraction and income from crops as well as farm size. The more water the farmer abstracts from the river, the higher the yields from the farms and income from the sale of the crop yields. Higher farm acreage enables the farmer to diversify crop production. This gives the farmer higher opportunity of obtaining higher yields from the farm. The increasing population in SWUT basin and the surrounding urban areas has increased the demand for water leading to increase in water abstraction. Water abstraction projects to provide water for the rural households and the surrounding urban centers have increased in the recent past. Household characteristics such as household size, age, income, education and occupation do not have a significant influence on water abstraction. This is mostly so because some smaller households are able to abstract more water from the rivers since they employ technologies such as water pumps. Thus, the main drivers of water abstraction in this basin are agricultural development, rural-urban water supplies, population growth and climate change. This study recommends a review of the existing policies on water abstraction to ensure that water abstractions are sustainable. It is also recommended that Water Resources Authority (WRA) conduct regular visits in the study area to monitor water abstractions and weed out illegal abstractions. Licensing of water abstractors should be enhanced and public awareness campaigns conducted to educate farmers on the sustainable ways of abstracting water from the rivers.

\section{Acknowledgments}

The author's wishes to thank Kenya Meteorological Department (KMD) and Water Resources Authority (WRA) for availing rainfall and river discharge data used in this paper.

\section{Conflicts of interest}

The authors declare that there is no conflict of interest.

\section{References}

1. Jim B, Truls EB. The impact of hydropower development on the sediment budget of the river Beiarelva, Norway. Proceedings of symposium held during seventh IAHS Scientific Assembly at Foz do Iguacu, Brazil. 2005.

2. Poff NL, Allan JD, Palmer MA, et al. River flows and water wars: emerging science for environmental decision making. Frontiers in Ecology and the Environment. 2003;1(6):298-306.

3. Palmer MA, Reidy Liermann CA, Nilsson C, et al. Climate change and the world's river basins: anticipating management options. Frontiers in Ecology and the Environment. 2008;6(2):81-89.

4. Finer M, Jenkins CN. Proliferation of hydroelectric dams in the Andean Amazon and implications for Andes-Amazon connectivity. PLoS ONE. 2012;7(4):e35126. 
5. MEA. Ecosystems and human well-being: wetlands and water synthesis. Washington DC, World Resources Institute. 2005;80.

6. Chapin FS, Zavaleta ES, Sandra D. Consequences of changing biodiversity. Springer Nature Publishing AG. 2000;405:234-242.

7. Butchart SH, Walpole M, Collen B, et al. Global Biodiversity: Indicators of recent declines. American Association for Advancement of Science. New York. 2010;328(5982):1164-1168.

8. Muranga County Government. Murang'a County Integrated Development Plan 2013-2017. Nairobi; Government Printer. 2014.

9. Kimenju JK. Evaluating payment potential for environmental services and watershed conservation of Thika Dam, Muranga County Kenya. Msc Thesis, Kenyatta University. 2018;264.

10. Okoola RE. Space-Time Characteristics of the ITCZ over Equatorial Eastern Africa during Anomalous Years. Phd Thesis, Department of Meteorology, University of Nairobi. 1996.

11. Onduru D, Muchena F. Cost Benefit Analysis of Land Management Options in the Upper Tana. Green Water Credits Report 15. ISRIC, Wageningen. $2011 ; 136$.

12. Otieno FAO, Maingi SM, Gichuki FN, et al. Sedimentation problems of Masinga reservoir. In Land and water management in Kenya: towards sustainable land use. Proceedings of the Fourth National Workshop, Kikuyu, Kenya, 15-19 February, 1993. (pp. 43-46). Soil and Water Conservation Branch, Ministry of Agriculture and Rural Development. 2000 .

13. Leisher. Maragua and Thika-Chania Baseline Survey for the Upper Tana Water Fund. The Nature Conservancy, UNDP, SACDEP, KENFAP and Pentair. 2013.

14. AWSB. Environmental Impact Assesment Study Report for Augementation and Rehabilitation of Gatanga Water Supply. Nairobi; Government Printer. 2004.

15. The Nature Conservancy. Upper Tana-Nairobi water fund business case. Version 2. Nairobi, Kenya: The Nature Conservancy. 2015.

16. Agwata JF. Resource Potential of the Tana Basin with Particular Focus on the Bwathonaro Watershed, Kenya, Participatory Watershed Management Plan, FWU. 2006;5.

17. KNBS. 2009 Kenya Housing and Population Census. Kenya National Bureau of Statistics. 2010.

18. Pallant J. SPSS Survival Manual: A step by step guide to data analysis using SPSS. Australia: Allen \& Unwin. 2011.

19. Mwadini K. Management practices of irrigation water and their effects on water allocation among farmers in Kiladeda Sub-catchment, Tanzania. (Masters Thesis) Kenyatta University, Kenya. 2018;146.

20. Aseyehegn K, Yirga C, Rajan S. Effect of Small-scale irrigation on the income of rural farm households: The case of Laelay Maichew district, Central Tigray, Ethiopia. The Journal of Agricultural Sciences. 2012;7(1):43-57.

21. Zhang L. Water, food and markets Household-level impact of irrigation water policies and institutions in Northern China (Doctoral Thesis). Wageningen University, Wageningen, The Netherlands. 2013.

22. Ramirez O, Beck R, Ghunaim A, et al. Factors affecting agriculture water use in the Mafraq Basin of Jordan: Quantitative Analyses and Policy Implications Jordan Component of the Sustainable Development of Drylands (No. 7). Jordan: New Mexico State University College of Agriculture. 2008

23. Adeoti AI. Factors influencing irrigation technology adoption and its impact on household poverty in Ghana. Journal of Agriculture and Rural Development in the Tropics and Subtropics. 2009;109(1):51-63.
24. Owilla BP. Analysis of economic efficiency of irrigation water-use in Mwea irrigation scheme, Kirinyaga District, Kenya (Master's Thesis). Kenyatta University, Nairobi, Kenya. 2010.

25. Alufah S. Adoption of Soil and Water Conservation Technologies for sustainable Watershed Management and Planning in Ngaciuma Subcatchment,Kenya (Unpublished Master's Thesis). Kenyatta University, Nairobi, Kenya. 2000.

26. Chebil A, Frija A, Abdelkafi B. Irrigation water use efficiency in collective irrigated schemes of Tunisia: Determinants and potential irrigation cost reduction. Agricultural Economics Review. 2012;13(1):1-15.

27. Getacher T, Mesfin A, Gebre-Egziabher G. Adoption and impacts of an irrigation technology: Evidence from household level data in Tigray, Northern Ethiopia. Universal Journal of Agricultural Research. 2014;1(2):030-034.

28. Mattias T. Studies of the waterscape of Kilimanjaro, Tanzania Water management in hill furrow irrigation (Doctoral Thesis). Norwegian University of Science and Technology, Norway. 2010.

29. Kossa RM, Mahoo HF, Hilmy S, et al. Water Abstraction and Use Patterns and Their Implications on Downstream River Flows: A case study of Mkoji Sub-catchment in Tanzania. International Water Management Institute. 2014.

30. IFAD/UNEP/GEF. Mount Kenya East Pilot Project for Natural Resource Management, Project brief Report, IFAD, UNEP, GEF. 2004.

31. Geertsma R, Wilschut L, Kauffman JH. Review for the Green Water Credits Pilot Operations in Kenya. Green Water Credits Report 8 / ISRIC Report 2010/02, ISRIC- World Soil Information, Wageningen. 2011.

32. Ngigi SN, Savenije HHG, Gichuki FN. Land use changes and hydrological impacts related to upscaling of rainwater harvesting and management in the Upper Ewaso Ng'iro river basin, Kenya. Land Use Policy. 2007;24:129140 .

33. Musau J, Sang J, Gathenya J, et al. Hydrological responses to climate change in Mt. Elgon watersheds. Journal of Hydrology: Regional Studies. 2015;3:233-246.

34. Howard G, Batram J, World Health Organisation. Domestic water quantity, service level and Health. Geneva, WHO. 2003.

35. Mokaya B. The effects of hydrological characteristics of river Nyakomisaro on the water supply of Kisii municipality, Kenya. Msc Thesis, Kenyatta University. 2015;131.

36. Dawdy DR, Bergmann JM. Effect of rainfall variability on streamflow simulation. John Wiley and Sons. 1969;5(5):958-966.

37. Bekele M. Effects of Rainfall Variability on Streamflow and its impacts on Small Scale Irrigation: The case of Gademso River, Central Rift Valley of Ethiopia. AAU Institutional Repository. 2013.

38. Meron TT, Willems P. Temporal Variability of Hydro-Climatic Extremes in the Blue Nile Basin. Water Resource Research. 2012;48(3):W03513.

39. Gichuki FN, Liniger HP, MacMillan LC, et al. Scarce Water: Exploring Resource Availability, Use and Improved Management. Eastern and Southern Africa Geographical Journal. 1998;8:15-28.

40. Speelman S. Water use efficiency and influence of management policies, analysis for the small-scale irrigation sector in South Africa (Doctoral Thesis). Ghent University, Ghent, Belgium. 2009.

41. Kimani E, Kombo DK. Gender and poverty reduction: A Kenyan context. Education Research and Reviews. 2010;5(1):024-030.

42. Rutaisire J, Kabonesa JK, Okechi PN. Lake Victoria Basin: Gender issues in fish farming. International Development Research Centre. 2010.

43. Mwangi GK. Adapting to climate change in Kenya, a case study of Ndeiya division, Kiambu County. Masters thesis, Kenyatta University. 2017. 
44. Michailidis A, Nastis SA, Loizou E, et al. The adoption of water saving irrigation practices in the Region of West Macedonia. European Association of Agricultural Economists. 2010;11.

45. Hussain I, Hussain Z, Sial MH. Water balance, supply and demand and irrigation efficiency of Indus basin. Pakistan Economic and Social Review. 2011;49(1):13-38

46. Shah T, Verma S, Pavelic P. Understanding smallholder irrigation in SubSaharan Africa: results of a sample survey from nine countries. Water International. 2013;38(6):809-826.
47. Amosson SH, Almas L, Bretz F, et al. Water management strategies for reducing irrigation demands in Region A. Prepared for Agricultural SubCommittee, Panhandle Water Planning Group. Amarillo, Texas: Texas A\&M University Agricultural Research and Extension Center. 2005;1-60.

48. Evans RG, Sadler EJ. Methods and technologies to improve efficiency of water use. Water Resources Research. 2008;44(7).

49. Mromba C. Effects of water abstraction on the riparian vegetation of Kiladeda River in Pangani river basin, Tanzania. Kenyatta University, Nairobi, Kenya. 2012. 